\title{
BIOMASS ESTIMATION AND MAPPING OF CAN GIO MANGROVE BIOSPHERE RESERVE IN SOUTH OF VIET NAM USING ALOS-2 PALSAR-2 DATA
}

\author{
LUONG, V. N. ${ }^{1 *}-$ TU, T. T. ${ }^{1}-$ KHOI, A. L. ${ }^{1}-$ HONG, X. T. ${ }^{1}-$ HOAN, T. N. ${ }^{2}-$ THUY, T. L. H. $^{2}$ \\ ${ }^{1}$ Space Technology Institute, Vietnam Academy of Science and Technology \\ 18 Hoang Quoc Viet str., Cau Giay dist., Hanoi 100000, Vietnam \\ ${ }^{2}$ Institute of Geography, Vietnam Academy of Science and Technology \\ 18 Hoang Quoc Viet str., Cau Giay dist., Hanoi 100000, Vietnam \\ *Corresponding author \\ e-mail: nvluong@sti.vast.vn; phone: +84-2437-562-985; Fax: +84-2437-914-622
}

(Received 24 $4^{\text {th }}$ Jul 2018; accepted $14^{\text {th }}$ Nov 2018)

\begin{abstract}
In this study, we used radar data from the ALOS-2 PALSAR-2 satellite to build biomass estimation models and then create a biomass map in Can Gio Mangrove Biosphere Reserve. We used the single variable regression and multivariate regression method, in which 30 sample plots for training model and 15 sample plots for validation model, the coefficient of determination $\left(\mathrm{R}^{2}\right)$ and root mean square error (RMSE) were used as metrics for evaluating the biomass estimates. The regression analyses showed that the HV polarization was highly related to the biomass, linear model $\left(R^{2}=0.74\right.$; RMSE $=28.16)$, exponential model $\left(R^{2}=0.69 ;\right.$ RMSE $\left.=28.73\right)$, and polynomial model $\left(R^{2}=0.76\right.$; RMSE $=28.03)$. However, the HH polarization did not show a high relationship with the above-ground biomass, linear model $\left(R^{2}=0.42\right)$, exponential model $\left(R^{2}=0.46\right)$, or polynomial model $\left(R^{2}=0.42\right)$. We also tried multiple linear regression between the parameters extracted from radar image $\mathrm{HH}, \mathrm{HV}$, and textures) and field biomass. The coefficient of determination $\left(\mathrm{R}^{2}\right)$ between the biomass and two independent variables ( $\mathrm{HH}$ and $\mathrm{HV}$ ) was 0.79, and RMSE was 29.78. However, the model with the combination of $\mathrm{HV}$ variable and eight texture variables provided a better result $\left(\mathrm{R}^{2}=0.81\right.$; RMSE $=$ 27.76 ), in other word the model could explain $81 \%$ variation of forest biomass. This model was used to produce the aboveground biomass map in Can Gio Biosphere Reserve in South of Vietnam.
\end{abstract}

Keywords: microwave data, $H H$ polarization, $H V$ polarization, backscattering, textures, model, mangrove ecosystem, Vietnam

\section{Introduction}

Mangroves are unique ecosystems that occur along ocean coastlines throughout the tropics and are the most carbon-rich forests in those regions. The economic potential of mangroves stems from three main sources, namely, forest products, estuarine and nearshore fisheries, and ecotourism (FAO, 1994; Cannicci et al., 2008; Donato et al., 2011; Alongi, 2012).

Climate change has been one of the biggest challenges for most countries in the $21^{\text {st }}$ century. (IPCC, 2001; Raghuvanshi et al., 2008), carbon dioxide $\left(\mathrm{CO}_{2}\right)$ is one of a primary interactant of global warming (IPCC, 2011; Rogelj et al., 2016). Forest sequestrate atmospheric $\left(\mathrm{CO}_{2}\right)$ in the form of plant biomass during photosynthesis (IPCC, 2003; Drégelyi-Kiss et al., 2008). Mangrove forest has great potential for $\mathrm{CO}_{2}$ sequestration (Ong et al., 2004; Alongi et al., 2012). Mangrove forests account for only approximately $1 \%$ of the world's forests, but for about $10-14 \%$ of the $\mathrm{CO}_{2}$ sequestration. Therefore, if the mangrove ecosystem is destroyed, the resultant amount 
of gas emissions could be very high (Cannicci et al., 2008; Drégelyi-Kiss et al., 2008; Alongi, 2012).

In 1943, the mangrove forest area in Vietnam was 408,500 ha. It decreased from 400,000 ha in the 1960 s to 73,000 ha in the 1990 s, due to the use of herbicides during the Indochina War and conversion of mangroves for agriculture and aquaculture. In 2015, mangrove area increased to 270,000 ha due to government and donor-funded planting efforts and mangrove protection policies (Mai Sy Tuan, 2016).

Mapping and carbon stock data are important in determining conservation priorities for climate change mitigation efforts as well as implementing programs such as REDD + (Hutchison et al., 2014). However, until now, there is still uncertainty about the amount of carbon emissions caused by the loss of mangrove forests because there is insufficient data on carbon stocks in these ecosystems (Donato et al., 2011; Hutchison et al., 2014).

The estimation of forest biomass using remote sensing data has proved to be more advantageous than traditional method, because it has advantages such as technology, space, time and cost (Lu, 2006; Gibbs et al., 2007; Goetz et al., 2011). The main remote sensing data is available as; optical satellite, lidar and radar satellite (Lu, 2006).

\section{Optical satellite data}

Studies on the estimation of forest biomass using optical satellite images such as Tucker et al. (1973), Tucker (1977), and Sader et al. (1989) have been of interest since very early to this now-aday, and are usually about the use of plant indicators such as Normalized Difference Vegetation Index (NDVI) (Hamdan et al., 2013; Kamal et al., 2015; Wicaksono et al., 2016) and Leaf Area Index (LAI) (Wicaksono et al., 2016; Castillo et al., 2017). However, due to disadvantages of optical satellite data such as high saturation, clouds, especially in tropical regions, the applications of these indicators are limited.

\section{Lidar data}

Lidar provides an excellent source of data for estimating forest biomass because it has three-dimensional information about forests (Maclean, 1998; Chen, 2013). Hayashi et al. (2015) developed empirical models to estimate aboveground biomass (AGB) and canopy height from the Ice, Cloud, and land Elevation Satellite (ICESat)/Geoscience Laser Altimeter System (GLAS) data in Borneo. However, due to the trade off between cost, high processing capacity, and specialized software, the application of Lidar data for a large geographical area is very limited (Lu, 2006; Chen, 2013; Sinha et al., 2015).

\section{Radar satellite data}

Radar data is used for estimation of forest biomass with high potential because this data is not affected much from natural conditions such as at day-night time, cloud cover, other advantages such as temporal availability, large-scale coverage, and lower saturation (Wu, 1987; Gibbs et al., 2007; Le Toan et al., 2011; Sinha et al., 2015). The long-wavelength Synthetic Aperture Radar (SAR) satellite is expected to have much promise for forest biomass map estimates (MacRoberts, 2007; Smith and Brown, 2009; Le Toan et al., 2011). The backscattering value of L-band and P-band SAR data have demonstrated sensitivity to structure, cover, volume, and biomass of the forests penetrating into the branches and stems of trees (Sun et al., 2002; Balzter, 2001; Morel 
et al., 2011). A number of previous studies have shown an impressive relationship between the SAR data and biomass (Le Toan et al., 1992; Santos et al., 2010; Peregon et al., 2013).

Several researchers have reported saturation problems of the L-band SAR backscattering over highly varying levels of biomass (Imhoff, 1995; Luckman et al., 1997; Mermoz et al., 2015). However, numerous reports indicate that the L-band SAR backscattering was saturated at around 150-200 Mg/ha (Motohka et al., 2011; Avtar et al., 2013; Le Toan et al., 2013; Ni et al., 2014).

The major SAR techniques for estimates of woody volume and biomass attempted by a number of researchers so far are dual-wavelength SAR interferometry (Balzter, 2001), random volume over-ground model (Hajnsek et al., 2009), water cloud model (Cartus et al., 2012), a combination of forest structure and radiative transfer models (Brolly et al., 2012), and electromagnetic modeling (Mermoz et al., 2015). The models mentioned above are relatively complex and difficult to implement in practice. Only regression correlation models are relatively easy to apply (Le Toan et al., 1992; Englhart et al., 2011; Carreiras et al., 2013; Izuka and Tateish, 2014).

Over the last decade in Viet Nam, there have been several studies using satellite imagery for estimating biomass and forest timber, e.g. Bui et al. (2011) conducted a study on the leaf canopy biomass in Cat Tien National Park, Lam Dong province using ALOS AVNIR 2 image. Huong et al. (2011) used SPOT5 satellite image to estimate woody volume. However, these studies have used only optical image data. Due to the limited ability of optical satellite imagery in the estimation of mangrove forest biomass on the ground, the models constructed in these studies are often complex and have several intermediate steps, thus limiting the application. As an urgent and mandatory requirement from forested countries to participate in climate change adaptation and REDD programs (Saatchi et al., 2011). However, the estimation of biomass from satellite data is very challenging due to the diverse nature of forests, especially tropical forests (Sinha et al., 2015; Kumar et al., 2015).

The purpose of this study was to develop the best model for estimation of mangrove forest biomass and then to create a forest biomass map. In this study, we have used radar data from ALOS-2 PALSAR-2 (The Advanced Land Observing Satellite-2), a Japanese satellite launched in 2014, which operates in L-band radar and collects very high spatial resolution data.

\section{Study area}

Can Gio mangrove forest lie entirely in the Can Gio district of Ho Chi Minh city in South of Vietnam. The boundary ranges from Nha Be district in the north to the East Sea in the south and from Dong Nai and Ba Ria-Vung Tau provinces in the east to Long An in the west. The area measures $35 \mathrm{~km}$ from north to south and $30 \mathrm{~km}$ from east to west (Fig. 1).

Topographically, the Can Gio mangrove forest forms a basin with a minimum altitude range of $0 \mathrm{~m}-1.5 \mathrm{~m}$, in the northeastern sector of the forest, with downward inclines from the east, south, and west. The climate has two seasons, rainy season from May to October and dry season from November to April.

Plant diversity, about 105 plant species, belonging to 48 genera are found in Can Gio mangrove forest, including Rhizophora apiculata constituted the main part of the flora, together with other assemblages of Bruguiera gymnorrhiza, Bruguiera parviflora, 
Ceriops sp., Kandelia candel, Rhizophora mucronata, Sonneratia alba, Sonneratia ovata, Sonneratia casedar, Avicennia alba, A. officinalis, A. lanata (stunted trees in abandoned salt fields), Aegiceras majus, Thespesia populnea, Hibiscus tiliaceus, Lumnitzera racemose, Xylocarpus granatum, and Excoecaria agallocha (Tuan et al., 2002).

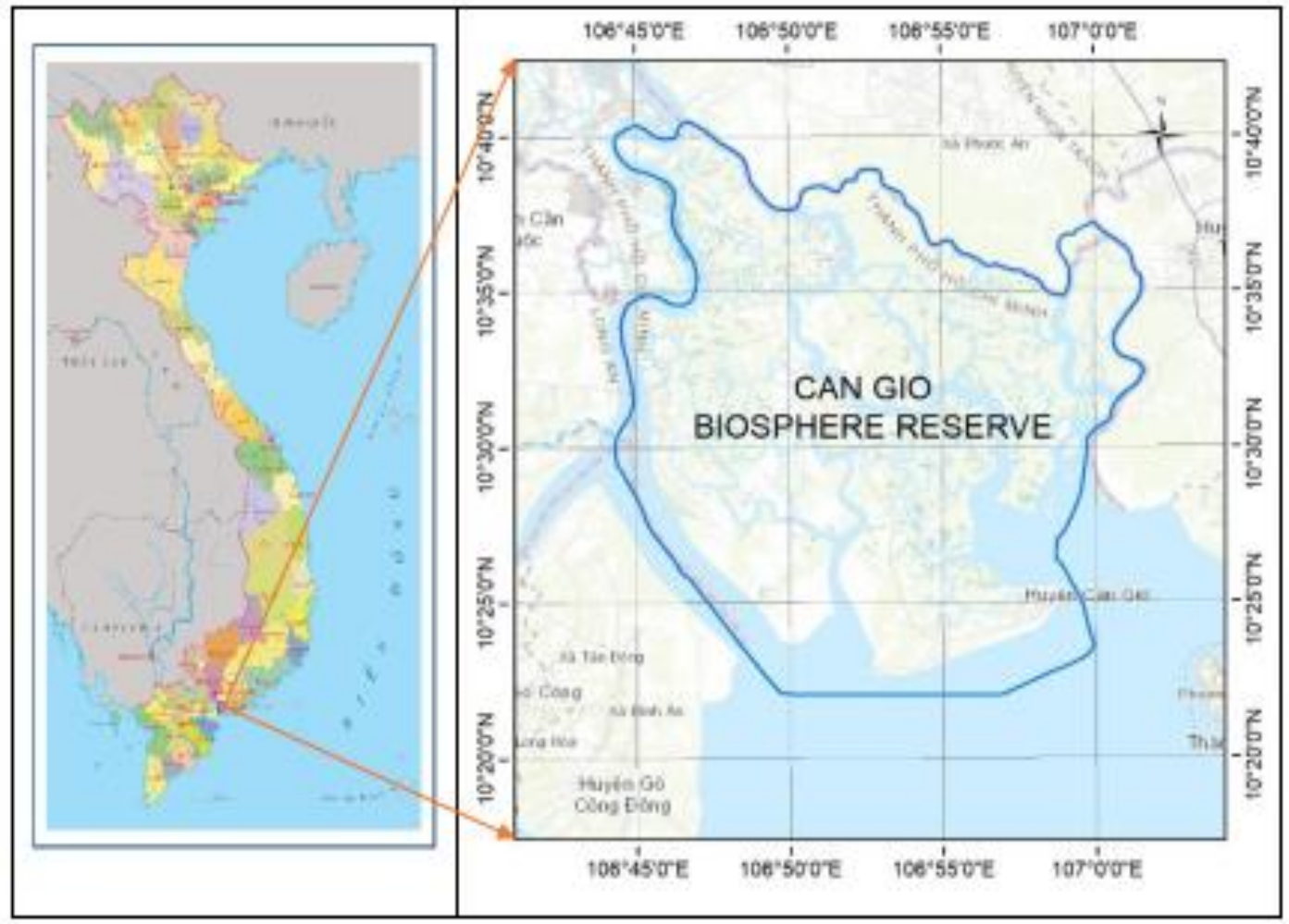

Figure 1. Study area position in Vietnam map (Can Gio Biosphere Reserve)

\section{Methodologies}

\section{Selection and processing of satellite data}

In this study, we used ALOS-2 PALSAR-2 version 2.1, HH (horizontal transmitting, horizontal receiving) and HV (horizontal transmitting, vertical receiving) polarizations with a pixel resolution of $6.25 \mathrm{~m}$, available as a geometrically corrected product. The digital number (DN) values of the SAR (Synthetic Aperture Radar) images in both the $\mathrm{HH}$ and $\mathrm{HV}$ polarizations were calibrated by calculating the backscattering intensity using Equation 1 (JAXA, 2014).

$$
\sigma^{\circ}=10 * \log _{10} \mathrm{DN}^{2}+\mathrm{CF}
$$

where:

$\sigma^{\mathrm{O}}$ is the sigma-naught backscattering intensity in the units of decibels $(\mathrm{dB})$.

$\mathrm{CF}$ is the calibration factor, which is currently set as -83 .

In this study, we also used eight texture values from ALOS-2 PALSAR-2 images, including contrast, correlation, dissimilarity, entropy, homogeneity, mean, second 
moment, and variance (Haralick et al., 1973; Anys et al., 1994). The formulas for the texture measurements used in this study are shown in Equations 2-9:

$$
\begin{aligned}
& \text { Contrast }=\sum_{n=0}^{N_{g}-1} n^{2} \sum_{\substack{i=1 \\
|\mathrm{i}-\mathrm{i}|=\mathrm{n}}}^{N_{g}} \sum_{j=1}^{N_{g}} p(i, j) \\
& \text { Dissimilarity }=\sum_{n=0}^{N_{g}-1} n \sum_{\substack{i=1 \\
|i-j|=n}}^{N_{g}} j \sum_{j=1}^{N_{g}} p(i, j)^{2} \\
& \text { Homogeneity }=\sum_{\mathrm{i}} \sum_{j} \frac{1}{1+(\mathrm{i}-\mathrm{j})^{2}} p\left(i_{v} j\right) \\
& \text { SecondMoment }=\sum_{i} j \sum_{j}\{p(i, j)\}^{2} \\
& \text { Correlation }=\frac{\sum_{\mathrm{i}} j \sum_{\mathrm{j}}\left(\mathrm{i}_{j} \mathrm{j}\right) p\left(\mathrm{i}_{v}, j\right)-\mu_{x} \mu_{y}}{\sigma_{x} \sigma_{y}} \\
& \text { Entropy }=\sum_{i} j \sum_{j} p(i, j) \log (p(i, j) \\
& \text { Mean }=\sum_{i, j=0}^{n-1} i p_{i, j} \\
& \text { Variance }=\sum_{i} j \sum_{j}(i-u)^{2}(p(i, j)
\end{aligned}
$$

where:

$\mathrm{p}(\mathrm{i}, \mathrm{j})$ is the normalized co-occurrence matrix such that sum $(\mathrm{i}, \mathrm{j}=0, \mathrm{n}-1, \mathrm{p}(\mathrm{i}, \mathrm{j}))=1$ $\mu_{\mathrm{x}}, \mu_{\mathrm{y}}, \sigma_{\mathrm{x}}, \sigma_{\mathrm{y}}$ are the means and standard deviations of $\mathrm{px}$, py.

The software used in this study included ENVI versions 5.4, ArcGIS 10.2 for satellite image processing, map editing, and $\mathrm{R}$ for statistical analysis. The details of the ALOS-2 PALSAR-2 data used in the research are shown in Table 1 and Figure 2.

Table 1. ALOS-2 PALSAR-2 data used in this research

\begin{tabular}{c|c|c|c|c|c}
\hline No. & Scene ID & Observation date & Observation angle & Polarizations & $\begin{array}{c}\text { Pixel resolution } \\
(\mathbf{m})\end{array}$ \\
\hline 1 & ALOS2151050200 & 10 March 2017 & $36.6^{\circ}$ & HH, HV & 6.25 \\
2 & ALOS2152303410 & 10 March 2017 & $36.6^{\circ}$ & HH, HV & 6.25 \\
\hline
\end{tabular}




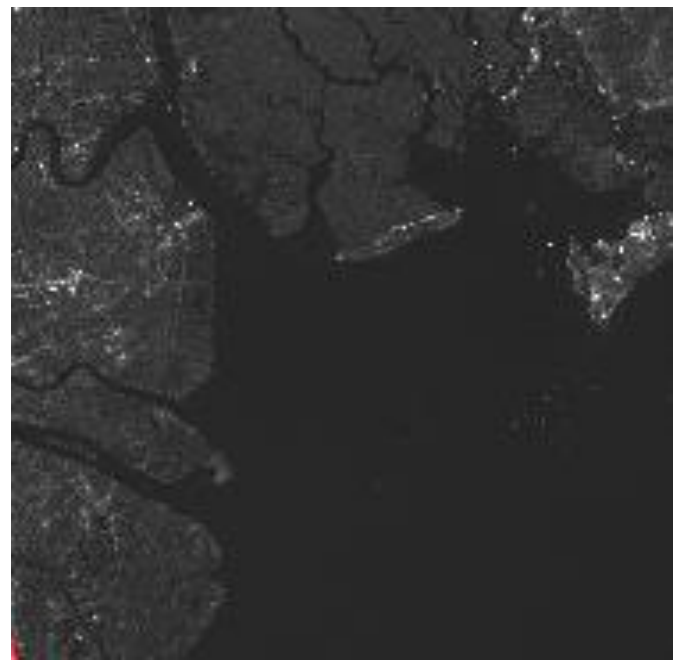

(a) ALOS2091020190

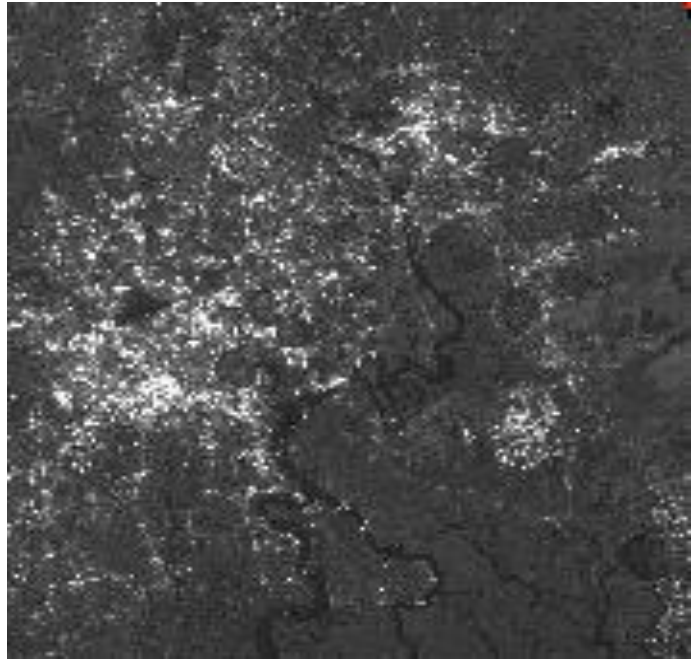

(b) ALOS2091020200

Figure 2. ALOS-2 PALSAR-2 data used in this research

\section{Field work}

Field surveys are important for collecting in situ data for accurate analysis of satellite-based estimates. We conducted a field survey during April 2017 to collect the ground truth data. In this study, the size of a sample plot is 0.05 ha $(20 \times 25 \mathrm{~m})$. We measured the diameter at breast height $\left(\mathrm{D}_{1.3 \mathrm{~cm}}\right)$ and tree height $\left(\mathrm{H}_{\mathrm{m}}\right)$. We also recorded the types of tree species during the field survey by Vietnam's flora books Pham (2003).

Forty-five sample plots in total are used in this study. We used a random selection method for training (30 sample plots) and validation data (15 sample plots). The inventory data summary is provided in Table 2. The distribution of the sample plot positions is shown in Figure 3.

Table 2. Forest inventory parameters for the training data

\begin{tabular}{c|c|c|c|c|c|c|c|c}
\hline \multirow{2}{*}{ Parameter } & \multicolumn{3}{|c|}{ Training field data } & \multicolumn{3}{c}{ Validation field data } \\
\cline { 2 - 9 } & Minimum & Maximum & Mean & $\begin{array}{l}\text { Standard } \\
\text { deviation }\end{array}$ & Minimum & Maximum & Mean & $\begin{array}{c}\text { Standard } \\
\text { deviation }\end{array}$ \\
\hline Diameter (m) & 5.83 & 17.60 & 10.16 & 3.25 & 7.11 & 17.60 & 11.62 & 2.93 \\
\hline Height (m) & 6.34 & 17.04 & 12.82 & 2.92 & 7.88 & 17.04 & 14.34 & 2.31 \\
\hline $\begin{array}{c}\text { Biomass } \\
\left(\text { Mg.ha }^{-1} \text { ) }\right.\end{array}$ & 9.24 & 254.29 & 99.20 & 76.90 & 11.31 & 255.42 & 179.52 & 67.60 \\
\hline
\end{tabular}

The survey results show that: Dense mangrove forests include dominant species as Rhizophora apiculata, Bruguiera gymnorrhiza, Avicennia germinans, Sonneratia caseolaris and Aegyceras corniculatum. Open mangrove forests include dominant species as Rhizophora apiculata, Avicennia germinans, Ceriops decandra, Lumnitzera racemonsa, Sonneratia caseolaris, and Lumnitzera racemosa. Young forests and scrubs include dominant species as Ceriops decandra, Lumnitzera racemosa, Avicennia germinans, and Rhizophora apiculata. The components of mangrove species in study area show in Table 3. 


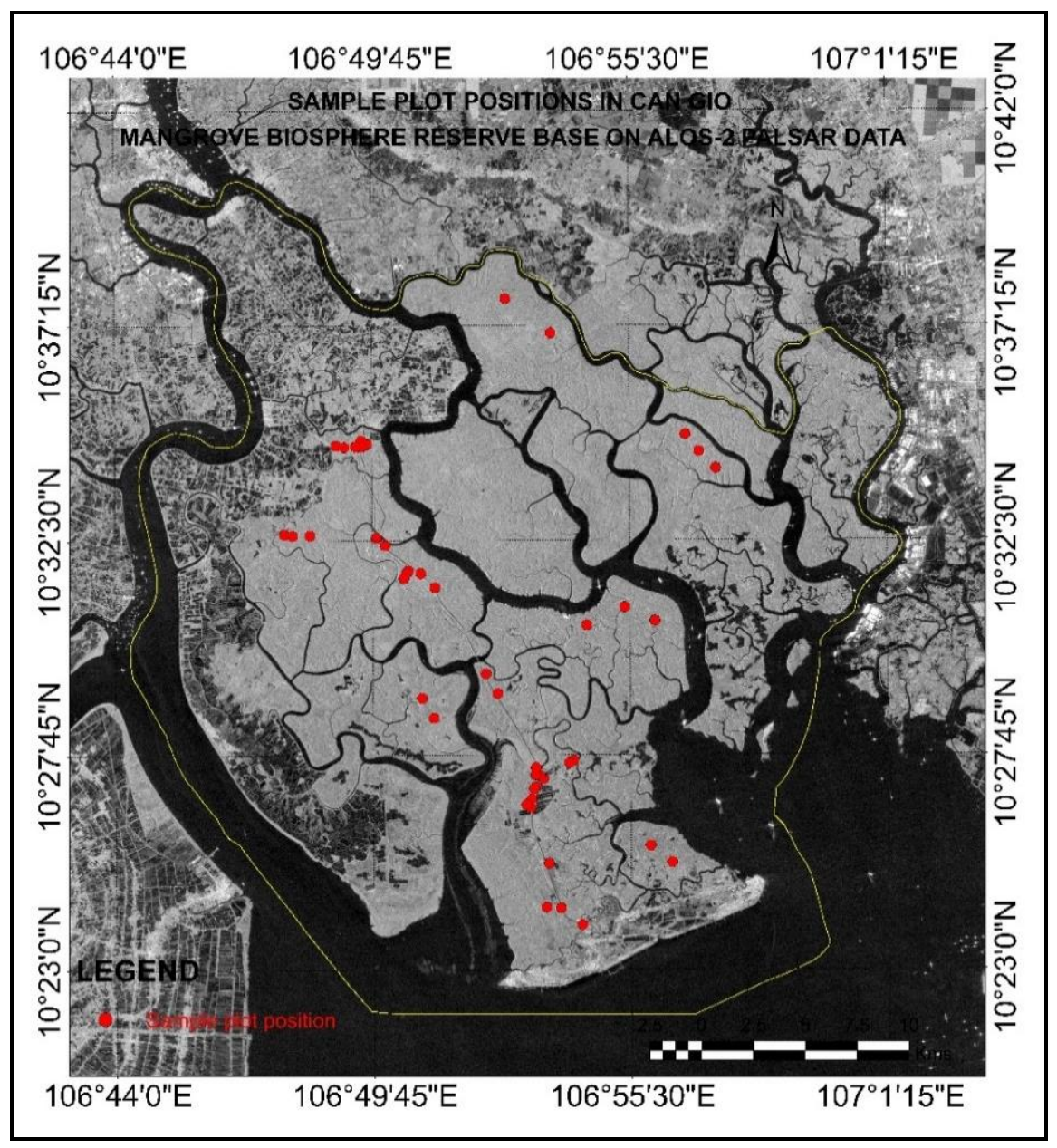

Figure 3. Sample plot position in Can Gio Biosphere Reserve

Table 3. The components of mangrove species in the study area

\begin{tabular}{|c|c|c|c|}
\hline No. & Forest classes & Sample plot number & $\begin{array}{c}\text { Components of mangrove species in the study } \\
\text { area by ratio 1/10 }\end{array}$ \\
\hline 1 & $\begin{array}{l}\text { Dense mangrove } \\
\text { forest }\end{array}$ & $\begin{array}{r}15,17,19,20, \\
42,44, \mathrm{a}\end{array}$ & $\begin{array}{c}7.93 \text { Rhizophora apiculata }+0.95 \text { Bruguiera } \\
\text { gymnorrhiza }+0.86 \text { Avicennia decandra }+0.25 \\
\text { Sonneratia caseolaris }+0.01 \text { Aegyceras } \\
\text { corniculatum }\end{array}$ \\
\hline 2 & $\begin{array}{l}\text { Open mangrove } \\
\text { forests }\end{array}$ & $\begin{array}{c}5,8,9,10,11,12,13,14 \\
21,22,28,33,34,35,36 \\
38,41, \text { and } 43\end{array}$ & $\begin{array}{c}\text { 2.91 Rhizophora apiculata }+2.91 \text { Avicennia } \\
\text { germinans }+1.58 \text { Ceriops decandra }+1.44 \\
\text { Lumnitzera racemonsa }+0.83 \text { Bruguiera parviflora } \\
+0.43 \text { Sonneratia caseomosa }+0.07 \text { Lumnitzera } \\
\text { racemosa }+0.03 \text { other species }\end{array}$ \\
\hline 3 & $\begin{array}{l}\text { Young forests and } \\
\text { scrubs }\end{array}$ & $\begin{array}{c}1,2,3,4,6,7,16,18,23 \\
24,25,26,27,29,30,31 \\
\text { and } 32\end{array}$ & $\begin{array}{l}8.55 \text { Ceriops decandra }+0.70 \text { Lumnitzera } \\
\text { racemosa }+0.70 \text { Avicennia germinans }+0.03 \\
\text { Rhizophora apiculata }+0.03 \text { other species }\end{array}$ \\
\hline
\end{tabular}

We used allometric equations (Eq. 10-18) here to calculate the AGB (Above Ground Biomass) for different mangrove species as well as the main species in the study area's mangrove forest. The equations are shown in Table 4. 
Table 4. Allometric equations used for mangroves species

\begin{tabular}{|c|c|c|c|}
\hline Species & Allometric equations & References & Eq. No. \\
\hline Rhizophora appiculata & AGB $=0.235 * D^{2.42}\left(R^{2}=0.98\right)$ & Ong et al. (2004) & (Eq.10) \\
\hline Avicennia germinans & AGB $=0.140 * D^{2.40}\left(R^{2}=0.97\right)$ & Fromard et al. (1998) & (Eq.11) \\
\hline Bruguiera gymnorrhiza & AGB $=0.186 * D^{2.31}\left(R^{2}=0.99\right)$ & Clough and Scott (1989) & (Eq.12) \\
\hline Bruguiera parviflora & AGB $=0.168 * D^{2.42}\left(R^{2}=0.99\right)$ & Clough and Scott (1989) & (Eq.13) \\
\hline Xylocarpus granatum & AGB $=0.0823 * D^{2.59}\left(R^{2}=0.99\right)$ & Clough and Scott (1989) & (Eq.14) \\
\hline Ceriops decandra & AGB $=0.208 * D^{2.96}\left(R^{2}=0.96\right)$ & Cao (2007) & (Eq.15) \\
\hline Lumnitzera racemosa & $\mathrm{AGB}=0.74 * \mathrm{D}^{2.92}\left(\mathrm{R}^{2}=0.99\right)$ & Trung et al. (2009) & (Eq.16) \\
\hline Sonneratia caseolaris & AGB $=0.199 * \rho^{0.90} * \mathrm{D}^{2.22}\left(\mathrm{R}^{2}=0.99\right)$ & Komiyama et al. (2005) & (Eq.17) \\
\hline Common equation & AGB $=0.25 * \rho * D^{592}\left(R^{2}=0.98\right)$ & Komiyama et al. (2005) & (Eq.18) \\
\hline
\end{tabular}

In allometric Equations 10-18:

- AGB is the aboveground biomass of a tree in kilograms $(\mathrm{kg})$

- $\mathrm{D}$ is the diameter at breast height $(1.3 \mathrm{~m})$ in centimeters $(\mathrm{cm})$

- $\rho$ is the wood density (tons dry matter $/ \mathrm{m}^{3}$ fresh volume) (IPCC, 2003)

\section{Results}

\section{Training of biomass model}

Coefficient of determination $\left(\mathrm{R}^{2}\right)$ and root mean square error (RMSE) were used as metrics for evaluating relationships. The results of the relationship between each backscattering intensity ( $\mathrm{HH}, \mathrm{HV}$ polarizations) and biomass value on the basis of the field observation plot were analyzed using the coefficient of determination $\left(\mathrm{R}^{2}\right)$. The assessment of these relationships has been shown by regression lines: The HV polarization was highly related to the biomass, according to the linear model $\left(\mathrm{R}^{2}=0.74\right.$; RMSE $=28.16)$, exponential model $\left(\mathrm{R}^{2}=0.69 ; \mathrm{RMSE}=28.73\right)$, and polynomial model $\left(\mathrm{R}^{2}=0.76\right.$; RMSE $\left.=28.03\right)$; whereas the HH polarization did not show a significant relationship with the aboveground biomass according to the linear, exponential, and polynomial models $\left(\mathrm{R}^{2}\right.$ respectively were $0.42,0.46$, and 0.42$)$. The results are shown in Figure 4.

We also analyzed multiple linear regression between the parameters extracted $(\mathrm{HH}$, $\mathrm{HV}$, and textures) from the radar image from ALOS-2 PALSAR-2 and field biomass. As shown in Table 5, the adjusted coefficient of determination $\left(\mathrm{R}^{2}\right)$ between the biomass and two independent variables ( $\mathrm{HH}$ and $\mathrm{HV}$ ) was 0.79 and $\mathrm{RMSE}=29.48$; that of biomass and eight independent variables of textures (contrast, correlation, dissimilation, entropy, homogeneity, mean, second moment, variance) was 0.49 . We used a combination of backscattering and textures variables from $\mathrm{HH}$, the result obtained with $\mathrm{R}^{2}=0.58$. However, the adjusted coefficient of determination $\left(\mathrm{R}^{2}\right)$ for the combination was 0.82 and $\mathrm{RMSE}=27.56$. The summary of the relationship between the field-measured biomass and ALOS-2 PALSAR-2 data is shown in Table 5. 

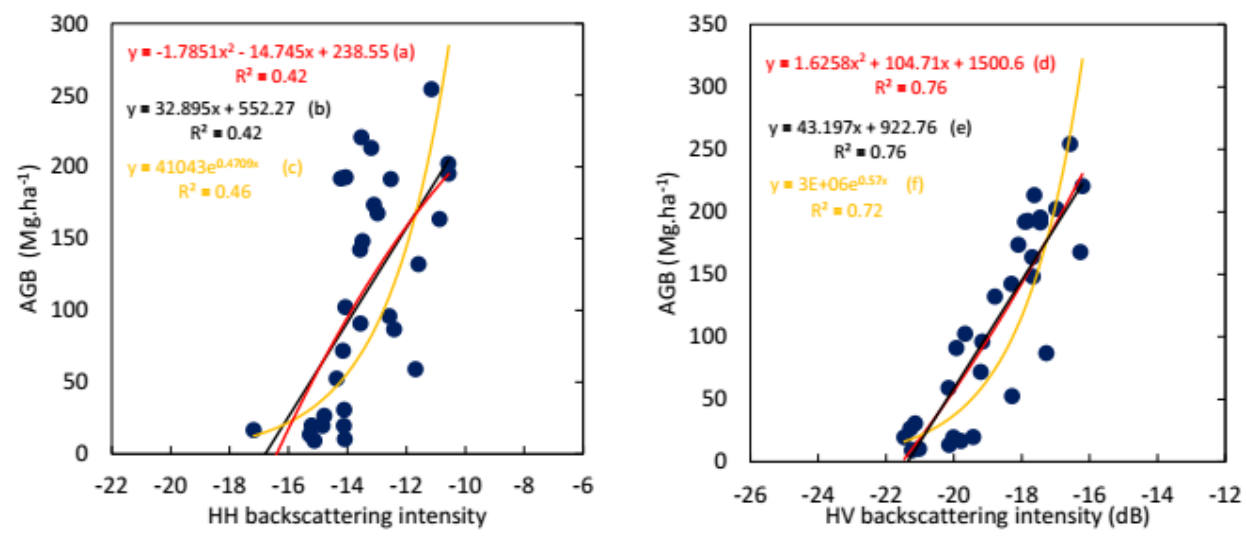

Figure 4. The relationship between biomass and L-band backscattering intensity: (a)

Polynomial model (Biomass and HH), (b) Linear model (Biomass and HH), (c) Exponential model (Biomass and HH), (d) Polynomial model (Biomass and HV), (e) Linear model (Biomass and $H V)$, and $(f)$ Exponential model (Biomass and $H V$ )

Table 5. The summary of the relationship between biomass and satellite data

\begin{tabular}{|c|c|c|c|}
\hline No. & Model & Relationship & $\begin{array}{c}\text { Coefficient of } \\
\text { determination }\left(\mathbf{R}^{2}\right)\end{array}$ \\
\hline & & Single-variable model & \\
\hline 1 & Model 1 & $\mathrm{AGB}=33.121 \mathrm{HH}+555.81$ & 0.42 \\
\hline 2 & Model 2 & $\mathrm{AGB}=44.318 \mathrm{HV}+945.99$ & 0.74 \\
\hline 3 & Model 3 & $\mathrm{AGB}=40278 \mathrm{e}^{0.4689 \times \mathrm{HH}}$ & 0.46 \\
\hline 4 & Model 4 & $\mathrm{AGB}=5 \mathrm{E}+06 \mathrm{e}^{0.5883 \times \mathrm{HV}}$ & 0.72 \\
\hline 5 & Model 5 & $\mathrm{AGB}=-2.4301 \mathrm{HH}^{2}-31.429 \mathrm{HH}+13$ & 0.42 \\
\hline \multirow[t]{2}{*}{6} & Model 6 & $\mathrm{AGB}=1.9415 \mathrm{HV}^{2}+118.03 \mathrm{HV}+1641.2$ & 0.76 \\
\hline & & Multil-variable model & \\
\hline 7 & Model 7 & $\mathrm{AGB}=957.79+11.58 \mathrm{HH}+36.79 \mathrm{HV}$ & 0.79 \\
\hline 8 & Model 8 & $\begin{array}{c}\mathrm{ABG}=-16817.86-1733.35 \text { Contrast }+49.90 \text { Correlation }+ \\
\text { 10249.89Dissimilarity }-254.70 \text { Entropy }+ \\
\text { 16974.67Homogenity }+23.41 \text { Mean }- \\
\text { 1084.849SecondMoment }+40.53 \text { Variance } \\
\end{array}$ & 0.49 \\
\hline 9 & Model 9 & $\begin{array}{c}\mathrm{ABG}=3084.31+168.53 \text { Contrast }+36.17 \text { Correlation }- \\
\text { 1090.15Dissimilarity }- \text { 89.71Entropy }-1729.60 \text { Homogenity }- \\
\text { 17.23Mean }-427.95 \text { SecondMoment }+16.09 \text { Variance }+ \\
\text { 39.53HH }\end{array}$ & 0.58 \\
\hline 10 & Model 10 & $\begin{array}{c}\mathrm{ABG}=-65714.04-6726.42 \text { Contrast }+2.46 \text { Correlation }+ \\
\text { 40273.92Dissimilarity }-115.77 \text { Entropy }+ \\
\text { 67144.71Homogenity }-6.04 \text { Mean }-432.67 \text { SecondMoment }+ \\
\text { 28.39Variance }+46.61 \mathrm{HV}\end{array}$ & 0.81 \\
\hline
\end{tabular}

\section{Validation of biomass model}

We have selected training models with $\mathrm{R}^{2}>0.7$ (high correlated) as validation models. Models $2\left(\mathrm{R}^{2}=0.74 ; \mathrm{RMSE}=28.16\right), 4\left(\mathrm{R}^{2}=0.72 ; \mathrm{RMSE}=33.64\right) 6$ $\left(\mathrm{R}^{2}=0.75 ; \mathrm{RMSE}=28.73\right), 7\left(\mathrm{R}^{2}=0.78 ; \mathrm{RMSE}=29.87\right)$, and $10\left(\mathrm{R}^{2}=0.81\right.$; RMSE $=27.76)$. The results of the validation model are shown in Figure 5. 




(a)

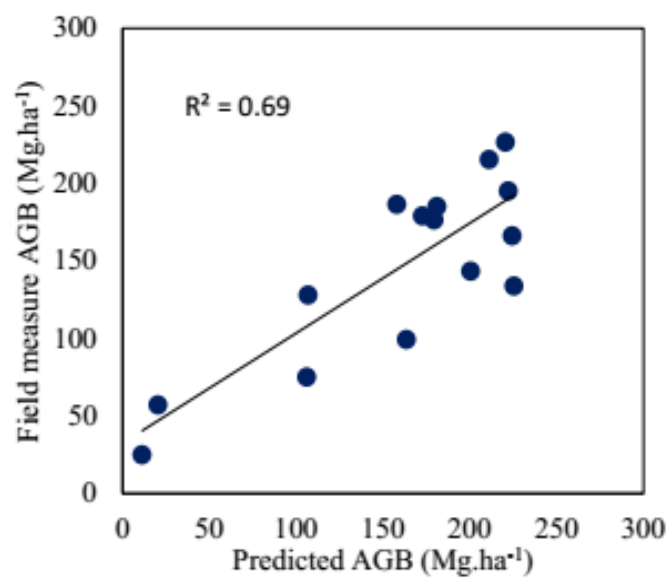

(c)



(b)

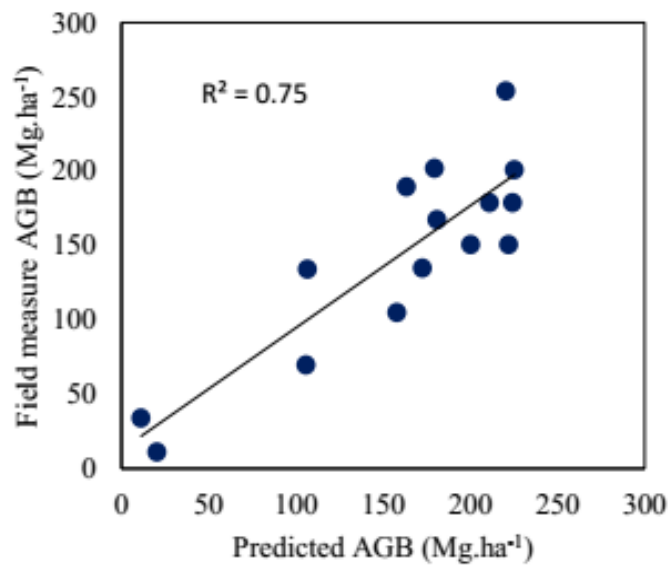

(d)

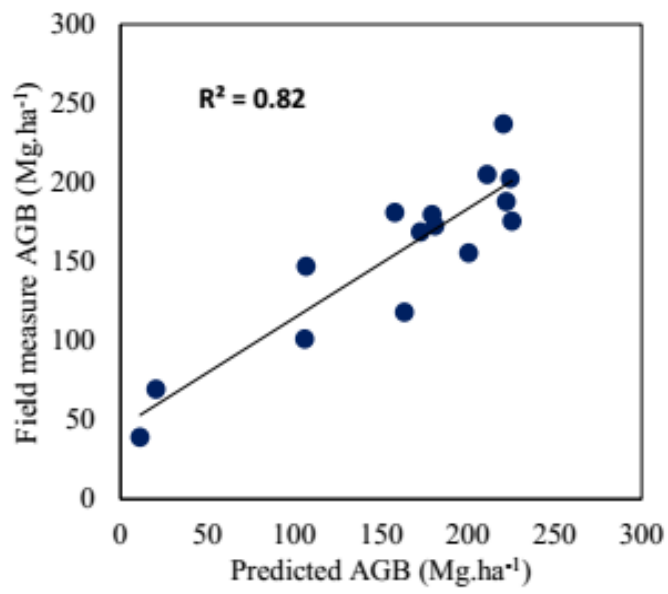

(e)

Figure 5. The validation results: (a) Model 2, (b) Model 4, (c) Model 6, (d) Model 7, and (e) Model 10. The 1:1 cross plots between the predicted and ground data are shown

We have found Model 10 to be the best, including training model $\left(\mathrm{R}^{2}=0.81\right.$; $\mathrm{RMSE}=27.76)$ and validation model $\left(\mathrm{R}^{2}=0.82 ; \mathrm{RMSE}=27.56\right)$, and have selected the Model 10 for map mangrove biomass for Can Gio Biosphere Reserve, Ho Chi Minh, city in South of Vietnam. 


\section{Mapping}

The model derived by the best combination of the HV backscattering intensity and eight textures from ALOS-2 PALSAR-2 (Model 10) is shown below:

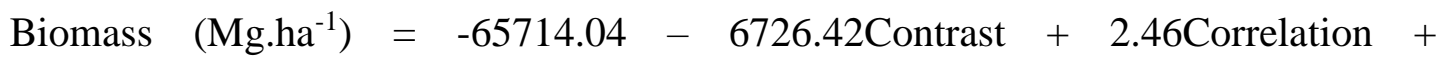
40273.92Dissimilarity - 115.77Entropy + 67144.71Homogenity - 6.04Mean 432.67SecondMoment + 28.39Variance + 46.61HV

This model was used to produce the aboveground biomass map in Can Gio Biosphere Reserve, Ho Chi Minh city in South of Vietnam. The results show that very rich mangrove forest is 13843.66 ha (18.45\%), rich mangrove forest area is 20188.03 ha (26.90\%), medium mangrove forest area is 7517.89 ha $(10.02 \%)$, poor mangrove forest area is 4648.30 ha $(6.19 \%)$, bare soil area is 730.30 ha $(0.97 \%)$, and the water body area is 28120.15 ha (37.47\%). More details are shown in Table 6 and the biomass map is shown in Figure 6.

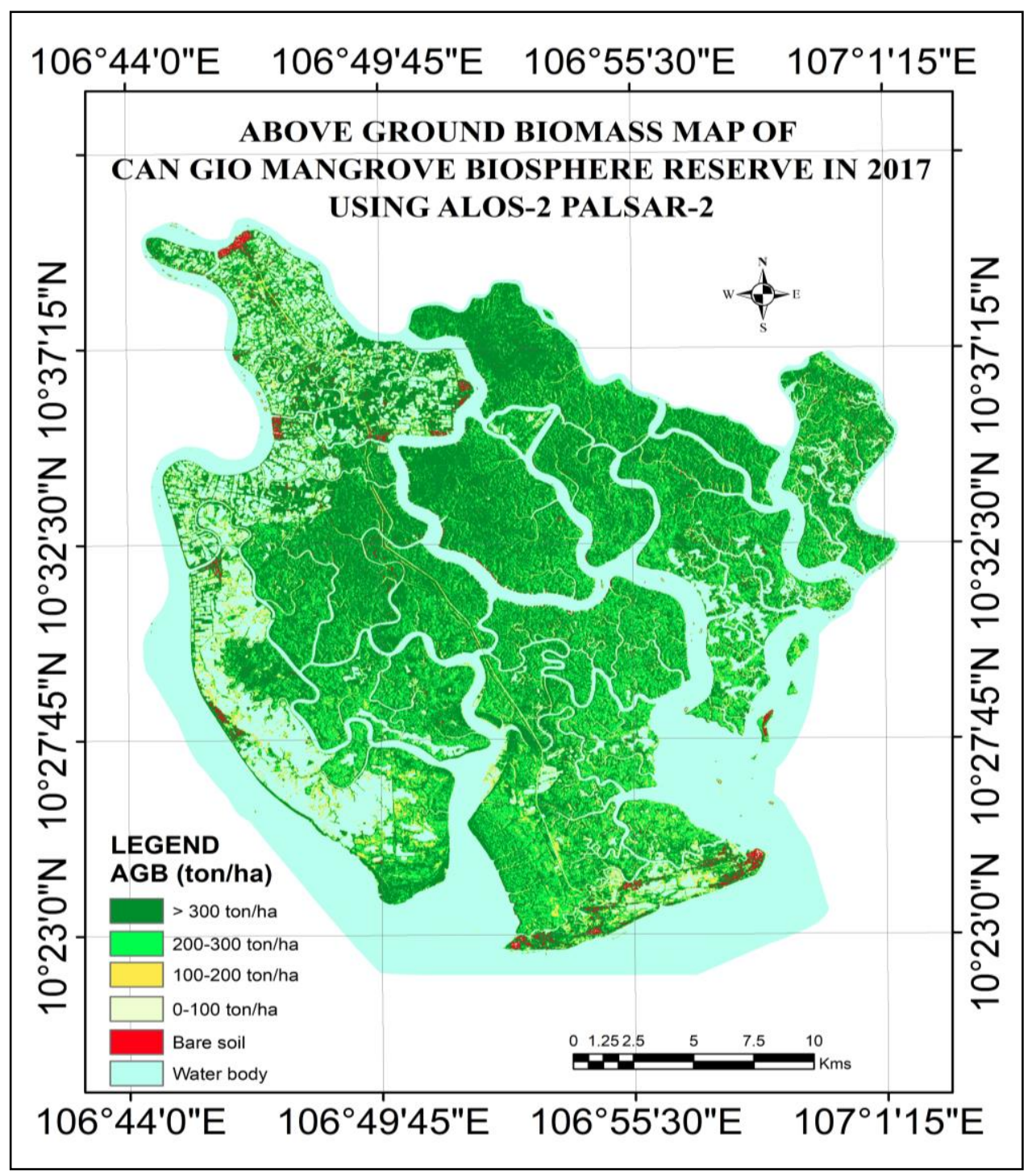


Figure 6. Aboveground biomass map of Can Gio Biosphere Reserve

Table 6. Aboveground biomass distribution of Can Gio Biosphere Reserve

\begin{tabular}{c|c|c|c|c}
\hline \multirow{2}{*}{ No. } & \multirow{2}{*}{ Classes } & \multirow{2}{*}{ Biomass level (ton.ha-1) } & \multicolumn{2}{|c}{ Area } \\
\cline { 3 - 5 } & & $>300$ & (ha) & $\mathbf{( \% )}$ \\
\hline 1 & Vey rich forest & $200-300$ & 13843.66 & 18.45 \\
2 & Rich forest & $100-300$ & 75188.03 & 26.90 \\
3 & Medium forest & $0-100$ & 4648.73 & 10.02 \\
4 & Poor forest & - & 730.30 & 6.19 \\
5 & Bare soil & - & 28120.15 & 0.97 \\
6 & Water body & & $\mathbf{7 5 0 4 8 . 7 6}$ & $\mathbf{1 0 0 . 0 0}$ \\
\hline
\end{tabular}

\section{Discussion}

The sensitivity of the radar signal to the biomass depends on the frequency, polarization, and incidence angle (Le Toan et al., 1992; Dobson et al., 1992; Van Truong et al., 2017). The forest structure is a complex matter; and the radar signal is sensitive to forest's characteristics as well as the horizontal and vertical structure of the forest. The L-band ALOS-2 PALSAR-2 data can penetrate into the forested canopy, and the backscattering is sensitive to the size of branches and tree trunks, which are main component of the forest biomass. The backscattering intensity received by a SAR sensor is characterized by the polarized (horizontal or vertical) combinations of the transmitted and received signals (Anys et al., 1994; Izuka et al., 2015; Kumar et al., 2015). The HH polarization receives the signal reflected straight from an object. Therefore, it is more sensitive to changes in moisture, and thus the HH backscattering intensity varies highly between dry or wet objects. Conversely, the HV polarization receives a signal reflected at a 90 degree angle from an object. In other words, the HV polarization receives a very different signal reflected at a different angle away from the received direction. Forest structures are complex in nature, resulting in volumetric rather than surface scattering. Therefore, HV data is more sensitive to the biomass than $\mathrm{HH}$ data. The structural information obtained from the SAR data provides additional information about the forest canopy structure (combination of horizontal and vertical forest structures). Thus, the combination of backscattering and textural parameters from SAR data has improved the model of biomass estimation in this study.

Some literature overviews of satellite data application for biomass estimation have been reviewed by Sinha et al. (2015), Tsitsi et al. (2016), and Kumar and Mutanga (2017). They have concluded that radar satellite data are more potential for biomass estimates especially in the tropical forest region, where forest structures are complex and often covered by clouds. Recent studies have also shown promising results for the estimation of forest biomass using satellite radar data. For example, Basuki et al. (2013) reported $\mathrm{R}^{2}$ from 0.70 to 0.75 for biomass estimates; Minh et al. (2018) have obtained high correlation $\left(\mathrm{R}^{2}=0.71\right)$ between the radar signal and in situ biomass, Ghosh and Behera (2018) have estimated aboveground biomass with high accuracy $\left(R^{2}=0.71\right)$, and Berninger et al. (2018) have also shown high model performance $\left(\mathrm{R}^{2}=0.70-0.76\right)$. Other studies have also obtained high correlation between the mangrove forest biomass and radar data. For example, Pham et al. (2018) got $\mathrm{R}^{2}=0.59$ between biomass and radar data, Argamosa et al. (2018) obtained high correlation $\left(\mathrm{R}^{2}\right.$ of 0.79$)$ between forest 
biomass and radar data. In general, major concerns of the researches are to improve the accuracy of the biomass estimates using satellite data, and our research is not an exception. Nevertheless, major limitation of the SAR system for estimating biomass is that the backscattering intensity becomes saturated when the biomass exceeds a certain critical value, even with the HV backscattering intensity. In this research, the bestvalidated model showed saturation point around 200-250 Mg.ha' ${ }^{-1}$ Therefore, the model presented in the research is sensitive to the biomass until that biomass value is reached.

\section{Conclusions}

In this study, we have developed a methodology for biomass estimation and mapping of mangrove forests. A case study in Can Gio Biosphere Reserve, Vietnam was conducted based on ALOS-2 PALSAR-2 data and field plot data. From the results of this study, we have obtained the following conclusions:

- HV polarization has a better relationship with mangrove forest biomass when compared to $\mathrm{HH}$ polarization in the single-variable model.

- Combined HV and HH polarization by multi-variable models have improved relationship to the biomass compared to single-variable models.

- We obtained $\mathrm{R}^{2}=0.58$ by the combination of backscattering variables and textures variables (contrast, correlation, dissimilation, entropy, homogeneity, mean, second moment, and variance) using $\mathrm{HH}$ polarization. However, by replacing the backscattering and textures variables from $\mathrm{HV}$ polarization, the model significantly improved $\left(\mathrm{R}^{2}=0.82\right.$; RMSE $\left.=27.56\right)$ the biomass estimates. This best model was used to produce an up-to-date biomass map of Can Gio Biosphere Reserve.

- The saturation in this study was found to be around 200-250 Mg.ha' ${ }^{-1}$. This result was improved compared to previous studies.

- The results showed that very rich mangrove forest is 13843.66 ha (18.45\%), rich mangrove forest area is 20188.03 ha $(26.90 \%)$, medium mangrove forest area is 7517.89 ha $(10.02 \%)$, and poor mangrove forest area is 4648.30 ha $(6.19 \%)$.

The estimation of mangrove forest biomass using the satellite data is important for monitoring mangrove biomass changes over time. We recommend monitoring of mangrove biomass changes every two years or at least every five years (according to the forest inventory period of Vietnam), using radar satellite data. Our hope is that the satellite based monitoring of mangrove forests can contribute significantly to the sustainable management of mangrove forests and to the participation on REDD+ programs.

Acknowledgements. The authors are grateful to the VT-UD. 05/17-20 project from National Research Program on Space Science and Technology for financial support to this research. We would like to thank JAXA for sharing ALOS-2 SAR data for this study in the framework of the ALOS Research program, PI No. 1172. 


\section{REFERENCES}

[1] Alongi, D. M. (2012): Carbon sequestration in mangrove forests. - Carbon Management 3(3): 313-322.

[2] Anys, H., Bannari, A., He, D. C., Morin, D. (1994): Texture analysis for the mapping of urban areas using airborne MEIS-II images. - Proceedings of the First International Airborne Remote Sensing Conference and Exhibition, Strasbourg, France, 12-15 September 1994, pp. 231-245.

[3] Avtar, R., Suzuki, R., Takeuchi, W., Sawada, H. (2013): PALSAR 50 m mosaic data based national level biomass estimation in Cambodia for implementation of REDD+ Mechanism. - PloS one 8(10): e74807.

[4] Balzter, H. (2001): Forest mapping and monitoring with interferometric synthetic aperture radar (InSAR). - Progress in Physical Geography 25(2): 159-177.

[5] Brolly, M., Woodhouse, I. H. (2012): A "Matchstick Model" of microwave backscatter from a forest. - Ecological Modelling 237: 74-87.

[6] Bui, N. L. H. et al. (2011): Estimating biomass of the canopy of leaves by using satellite data ALOS AVNIR-2. - National Workshop on GIS Applications, Vietnam, 2011.

[7] Cannicci, S., Burrows, D., Fratini, S., Smith, T. J., Offenberg, J., Dahdouh-Guebas, F. (2008): Faunal impact on vegetation structure and ecosystem function in mangrove forests: a review. - Aquatic Botany 89(2): 186-200.

[8] Cao, H. B. (2009): Nghiên cứu khả năng hấp thụ $\mathrm{CO}_{2}$ của quần thể dà quánh (Ceriops decandra Dong Hill) tự nhiên tại Khu Dự trữ sinh quyển rừng ngập mặn Cần Giờ, thành phố Hồ Chí Minh (Doctoral dissertation, Trường Đại học Nông Lâm TP. Hồ Chí Minh) (Vietnamese version). Study on the ability of $\mathrm{CO}_{2}$ absorption of the natural Ceriops decandra Dong Hill (Dà quánh) populations in Can Gio Mangrove Biosphere Reserve (Doctoral dissertation, Nong Lam University Ho Chi Minh City) (Translated by Luong, V.N).

[9] Carreiras, J. M. B., Melo, J. B., Vasconcelos, M. J (2013): Estimating the above-ground biomass in Miombo Savanna woodlands (Mozambique, East Africa) using L-band synthetic aperture radar data. - Remote Sens. 5: 1524-1548.

[10] Cartus, O., Santoro, M., Kellndorfer, J. (2012): Mapping forest aboveground biomass in the Northeastern United States with ALOS PALSAR dual-polarization L-band. - Remote Sensing of Environment 124: 466-478.

[11] Castillo, J. A. A., Apan, A. A., Maraseni, T. N., Salmo III, S. G. (2017): Estimation and mapping of above-ground biomass of mangrove forests and their replacement land uses in the Philippines using Sentinel imagery. - ISPRS Journal of Photogrammetry and Remote Sensing 134: 70-85.

[12] Chen, Q. (2013): Lidar remote sensing of vegetation biomass. - Remote Sensing of Natural Resources 399: 399-420.

[13] Clough, B. F. and Scott, K. (1989): Allometric relationships for estimating aboveground biomass in six mangrove species. - Forest Ecol. Manage. 27: 117-127.

[14] Dobson, M. C., Ulaby, F. T., LeToan, T., Beaudoin, A., Kasischke, E. S., Christensen, N. (1992): Dependence of radar backscatter on coniferous forest biomass. - IEEE Transactions on Geoscience and remote Sensing 30(2): 412-415.

[15] Donato, D. C., Kauffman, J. B., Murdiyarso, D., Kurnianto, S., Stidham, M., Kanninen, M. (2011): Mangroves among the most carbon-rich forests in the tropics. - Nature Geoscience 4(5): 293-297.

[16] Drégelyi-Kiss, Á., Drégelyi-Kiss, G., Hufnagel, L. (2008): Ecosystems as climate controllers-biotic feedbacks (a review). - Applied Ecology and Environmental Research 6(2): 111-135.

[17] Englhart, S., Keuck, V., Siegert, F. (2011): Aboveground biomass retrieval in tropical forests. The potential of combined X- and L-band SAR data use. - Remote Sens. Environ. 115: $1260-1271$. 
[18] FAO (1994): Mangrove Forest Management Guideline. - Food and Agriculture Organization of the United Nations, Roma.

[19] Fromard, F., Puig, H., Mougin, E., Marty, G., Betoulle, J. L., Cadamuro, L. 1998: Structure above-ground biomass and dynamics of mangrove ecosystems: new data from French Guiana. - Oecologia 115: 39-53.

[20] Gibbs, H. K., Brown, S., Niles, J. O., Foley, J. A. (2007): Monitoring and estimating tropical forest carbon stocks: making REDD a reality. - Environmental Research Letters 2(4): 045023.

[21] Goetz, S., Dubayah, R. (2011): Advances in remote sensing technology and implications for measuring and monitoring forest carbon stocks and change. - Carbon Management 2(3): 231-244.

[22] Hajnsek, I., Kugler, F., Lee, S. K., Papathanassiou, K. P. (2009): Tropical-forestparameter estimation by means of Pol-InSAR: The INDREX-II campaign. - IEEE Trans. Geosci. Remote Sens. 47: 481-493.

[23] Hamdan, O., Khairunnisa, M. R., Ammar, A. A., Hasmadi, I. M., Aziz, H. K. (2013): Mangrove carbon stock assessment by optical satellite imagery. - Journal of Tropical Forest Science 554-565.

[24] Haralick, R. M., Shanmugam, K., Dinstein, I. H. (1973): Textural features for image classification. - IEEE Trans. Syst. Man Cybern. 6: 610-621.

[25] Hayashi, M., Saigusa, N., Yamagata, Y., Hirano, T. (2015): Regional forest biomass estimation using ICESat/GLAS spaceborne LiDAR over Borneo. - Carbon Management 6(1-2): 19-33.

[26] Trung, V.P., Hoan, D.H., Sinh, V.L. (2009): Nghiên cứu khả năng tích tụ Carbon của rừng trồng Cóc trắng (Lumnitzera racemosa WILLD) tại khu dự trữ sinh quyển rừng ngập mặn Cần Giờ-Thành phố Hồ Chí Minh (Vietnamese version). Study on the ability of carbon storage by Lumnitzera racemosa WILLD in Can Gio Mangrove Biosphere Reserve, Ho Chi Minh City (Translated by Luong, V.N).

[27] Huong, N. T. T. (2011): Áp dụng phương pháp địa thông kê để ước lượng trữ lượng lâm phần dựa vào ảnh vệ tinh SPOT5 (2011). Tạp Chí Nông nghiệp và Phát triển Nông thôn, Kỳ 1, 2 tháng 2 năm 2011 (Vietnamese version). Applying geostatistic to estimate stand forest volume based on SPOT 5 data. - Journal of Agriculture and Rural Development, Vol. 1,2, February 2011 (Translated by Luong, V.N).

[28] Hutchison, J., Manica, A., Swetnam, R., Balmford, A., Spalding, M. (2014): Predicting global patterns in mangrove forest biomass. - Conservation Letters 7(3): 233-240.

[29] Iizuka, K., Tateishi, R. (2015): Estimation of $\mathrm{CO}_{2}$ sequestration by the forests in Japan by discriminating precise tree age category using remote sensing techniques. - Remote Sensing 7(11): 15082-15113.

[30] Imhoff, M. L. (1995): Radar backscatter and biomass saturation-Ramifications for global biomass inventory. - IEEE Transactions on Geoscience and Remote Sensing. 33 (2): 511 518. DOI: $10.1109 / 36.377953$.

[31] IPCC (2001): Climate Change 2001 IPCC Third Assessment Report. - Intergovernmental Panel on Climate Change Geneva, IPCC Secretariat.

[32] IPCC (2003): Good Practice Guidance for Land Use, Land-Use Change and Forestry. IPCC National Greenhouse Gas Inventories Programme Technical Support Unit, Japan.

[33] JAXA (2014): ALOS-2/Calibration Result of JAXA Standard Products. - Japan Aerospace Exploration Agency, Earth Observation Research Center, Tsukuba, Japan, 2014.

[34] Kamal, M., Phinn, S., Johansen, K. (2015): Object-based approach for multi-scale mangrove composition mapping using multi-resolution image datasets. - Remote Sensing 7(4): 4753-4783.

[35] Komiyama, A., Poungparn, S., Kato, S. (2005): Common allometric equations for estimating the tree weight of mangroves. - Journal of Tropical Ecology 21 (04): 471-477. DOI: $10.1017 /$ S0266467405002476. 
[36] Kumar, L., Sinha, P., Taylor, S., Alqurashi, A. F. (2015): Review of the use of remote sensing for biomass estimation to support renewable energy generation (2015). - J. Appl. Remote Sens. DOI: 10.1117/1.JRS.9.097696.

[37] Le Toan, T., Beaudoin, A., Riom, J., Guyon, D. (1992): Relating forest biomass to SAR data. - IEEE Transactions on Geoscience and Remote Sensing 30(2): 403-411.

[38] Le Toan, T.; Quegan, S.; Davidson, M. W. J.; Balzter, H.; Paillou, P.; Papathanassiou, K.; Ulander, L. (2011): The BIOMASS mission: mapping global forest biomass to better understand the terrestrial carbon cycle. - Remote Sens. Environ. 115: 2850-2860.

[39] Le Toan, T; Mermoz, S.; Bouvet, A.; Villard, L. K. C. (2013): Forest Cover Change and Biomass Mapping. - K\&C Initiative Report on an International Science Collaboration Led by JAXA, Tokyo, Japan.

[40] Lu, D. (2006): The potential and challenge of remote sensing-based biomass estimation. International Journal of Remote Sensing 27(7): 1297-1328.

[41] Luckman, A., Baker, J., Kuplich, M. T., Yanasse, F. C. C., Frery, C. A. (1997): A study of the relationship between radar backscatter and regenerating tropical forest biomass for spaceborne SAR instruments. - Remote Sens. Environ. 60: 1-13.

[42] Maclean, G. A. (1988): Estimation of foliar and woody biomass using an airborne lidar system. - Wisconsin Univ., Madison, WI (USA).

[43] Mai, S. T. (2016): Mangrove-related policy and institutional framework in Vietnam. MFF-FAO Final workshop for "Income for Coastal Communities for Mangrove Protection" Project, December 2016.

[44] McRoberts, R. E., Tomppo, E. O. (2007): Remote sensing support for national forest inventories. - Remote Sensing of Environment 110(4): 412-419.

[45] Mermoz, S., Réjou-Méchain, M., Villard, L., Le Toan, T., Rossi, V., Gourlet-Fleury, S. (2015): Decrease of L-band SAR backscatter with biomass of dense forests. - Remote Sensing of Environment 159: 307-317.

[46] Morel, A. C., Saatchi, S. S., Malhi, Y., Berry, N. J., Banin, L., Burslem, D., Ong, R. C. (2011): Estimating aboveground biomass in forest and oil palm plantation in Sabah, Malaysian Borneo using ALOS PALSAR data. - For. Ecol. Manag. 262: 1786-1798.

[47] Motohka, T., Shimada, M., Isoguchi, O., Ishihara, M. I., Suzuki, S. N. (2011): Relationships between PALSAR backscattering data and forest above ground biomass in Japan. - Geoscience and Remote Sensing Symposium (IGARSS), 2011 July, IEEE International, pp. 3518-3521.

[48] Ni, W., Zhang, Z., Sun, G., Guo, Z., He, Y. (2014): The penetration depth derived from the synthesis of ALOS/PALSAR InSAR data and ASTER GDEM for the mapping of forest biomass. - Remote Sensing 6(8): 7303-7319.

[49] Ong, J. E., Gong, W. K., Wong, C. H. (2004): Allometry and partitioning of the mangrove, Rhizophora apiculata. - Forest Ecology and Management 188(1-3): 395-408.

[50] Peregon, A.; Yamagata, Y. (2013): The use of ALOS/PALSAR backscatter to estimate above-ground forest biomass: A case study in Western Siberia. - Remote Sens. Environ. 137: 139-146.

[51] Pham, H. H. (2003): Flora of Viet Nam. Volume 1, 2, 3. - Young Publishing House, Ho Chi Minh City, Vietnam.

[52] Raghuvanshi, S. P., Raghav, A. K., Chandra, A. (2008): Renewable energy resources for climate change mitigation. - Applied Ecology and Environmental Research 6(4): 15-27.

[53] Rogelj, J., Den Elzen, M., Höhne, N., Fransen, T., Fekete, H., Winkler, H., ... Meinshausen, M. (2016): Paris Agreement climate proposals need a boost to keep warming well below 2 C. - Nature 534(7609): 631.

[54] Saatchi, S. S., Harris, N. L., Brown, S., Lefsky, M., Mitchard, E. T., Salas, W., Petrova, S. (2011): Benchmark map of forest carbon stocks in tropical regions across three continents. - Proc. Natl. Acad. Sci. USA 108: 9899-990. 
[55] Sader, S. A., Waide, R. B., Lawrence, W. T., Joyce, A. T. (1989): Tropical forest biomass and successional age class relationships to a vegetation index derived from Landsat TM data. - Remote Sensing of Environment 28: 143IN1159-156IN2198.

[56] Santos, J. R., Lacruz, M. P., Araujo, L. S., Keil, M. (2010): Savanna and tropical rainforest biomass estimation and spatialization using JERS-1 data. - International Journal of Remote Sensing 23(7): 1217-1229.

[57] Sinha, S., Jeganathan, C., Sharma, L. K., Nathawat, M. S. (2015): A review of radar remote sensing for biomass estimation. - International Journal of Environmental Science and Technology 12(5): 1779-1792.

[58] Sun, G., Ranson, K. J., Kharuk, V. I. (2002): Radiometric slope correction for forest biomass estimation from SAR data in the Western Sayani Mountains, Siberia. - Remote Sensing of Environment 79(2-3): 279-287.

[59] Tuan, L. D. et al. (2002): Can Gio Mangrove Biosphere Reserve. - Agriculture Publishing House, Ho Chi Minh City.

[60] Tucker, C. J. (1977): Use of Near Infrared/Red Radiance Ratios for Estimating Vegetation Biomass and Physiological Status. - NASA Goddard Space Flight Center, Greenbelt, MD, United States

[61] Tucker, C. J., Miller, L. D. (1973): The remote estimation of a grassland canopy: its biomass chlorophyll, leaf water, and underlying soil spectra. - Technical Report (US International Biological Program Grassland Biome) No 237.

[62] Van Truong, V., Duong, N. D., Tuan, T. A. (2017): Mapping land cover using multitemporal sentinel-1A data: A case study in Hanoi. - Vietnam Journal of Earth Sciences 39(4): 345-359.

[63] Wicaksono, P., Danoedoro, P., Hartono, Nehren, U. (2016): Mangrove biomass carbon stock mapping of the Karimunjawa Islands using multispectral remote sensing. International Journal of Remote Sensing 37(1): 26-52.

[64] Wu, S. T. (1987): Potential application of multipolarization SAR for pine-plantation biomass estimation. - IEEE Transactions on Geoscience and Remote Sensing (3): 403409. 